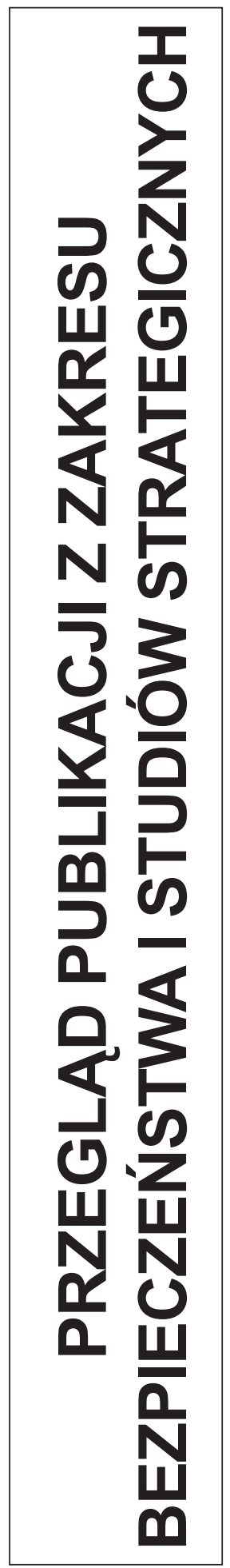





\section{POLSKIE ANALIZY STRATEGICZNE - PRZEGLĄD 2016 ROKU}

Niniejszy artykuł stanowi kolejną odsłonę przygotowywanego od dwóch lat przeglądu artykułów publikowanych w wybranych polskich czasopismach naukowych poświęconych tematyce bezpieczeństwa międzynarodowego. W odniesieniu do roku 2016 autor dokonał (siłą rzeczy) subiektywnego wyboru tekstów, które znalazły się na łamach czterech czasopism: „Bellony”, „Rocznika Bezpieczeństwa Międzynarodowego”, „Rocznika Strategicznego” oraz „Stosunków Międzynarodowych”. W naturalny sposób tematyka podejmowana przez autorów rzeczonych publikacji stanowi odzwierciedlenie obecnego stanu międzynarodowego środowiska bezpieczeństwa oraz prognoz co do kierunków jego dalszej ewolucji. W poprzednich edycjach przeglądu polskich analiz strategicznych jak w zwierciadle odbijała się postępująca destabilizacja ładu bezpieczeństwa szeregu kluczowych regionów świata (Azji Wschodniej, Bliskiego Wschodu oraz Europy). Rok 2016 przyniósł pogłębienie zjawisk kryzysowych i ogólnej niestabilności Bliskiego Wschodu oraz Azji Wschodniej. Natomiast w Europie można zaobserwować procesy, które potencjalnie mogą stanowić zwiastun dostosowania się ładu regionalnego do swoistej ,nowej normalności”. Wbrew licznym oczekiwaniom i prognozom ochłodzenie relacji między Federacją Rosyjska a wspólnotą transatlantycką nie okazało się być krótkotrwałym epizodem. Wydaje się, iż polityka sankcji gospodarczych oraz wzmacniania obecności wojskowej na tzw. „Wschodniej Flance” NATO nabiera cech średnioterminowej trwałości, a nawet instytucjonalizacji. Z drugiej strony, nie zmaterializowały się obawy odnośnie możliwości dalszej eskalacji napięcia i intensyfikacji incydentów o charakterze zbrojnym. Można zatem powiedzieć, iż w Europie Wschodniej nastąpiła pewnego rodzaju mała stabilizacja wyrażająca się w utrwaleniu nowych, antagonistycznych pozycji Rosji i Zachodu względem siebie. Chociaż częste wśród dziennikarzy i analityków porównania do nowej zimnej wojny są przedwczesne i nazbyt upraszczają obecną sytuację, to jednak można mówić o utrwaleniu (przynajmniej w średniookresowej perspektywie) antagonistycznego modelu relacji Federacji Rosyjskiej i wspólnoty transatlantyckiej.

Tak rozumianej, względnej, stabilizacji Europy towarzyszy postępująca destabilizacja regionalnych kompleksów bezpieczeństwa Azji Wschodniej i Bliskiego Wschodu. Jednak prawdopodobnie najbardziej zaskakującą nową tendencją 2016 r. jest pojawienie się nowych aktorów, czy raczej ognisk, niepewności i niestabilności w świecie. Do tej pory działania destabilizujące ład bezpieczeństwa (globalny lub regionalny) podejmowali przeważnie aktorzy otwarcie go odrzucający (np. Państwo Islamskie) lub uważani za co najmniej jego kontestatorów (Chińska Republika Ludowa i Federacja Rosyjska). Natomiast nowa dynamika polityczna w państwach Zachodu (uważanych 
za rdzeń obecnego ładu międzynarodowego oraz jego głównych beneficjentów) przejawiająca się w decyzji Brytyjczyków o opuszczeniu Unii Europejskiej oraz wyborze Donalda Trumpa na prezydenta USA, doprowadziła do sytuacji, w której państwa uważane za filary stabilności obecnego ładu międzynarodowego stały się ostatnio źródłem jeśli nie destabilizacji, to przynajmniej rosnącej niepewności w stosunkach międzynarodowych. Mamy zatem do czynienia z paradoksalną sytuacją, w której państwa, których polityka zagraniczna i bezpieczeństwa była do tej pory uważana za względnie obliczalną, stają się do pewnego stopnia nieprzewidywalne.

Tak skrótowo przedstawiona sytuacja międzynarodowa stanowi kontekst dla publikacji zamieszczonych w polskich czasopismach naukowych podejmujących problematykę bezpieczeństwa międzynarodowego. Omawiane w niniejszym przeglądzie artykuły można pogrupować w cztery obszary tematyczne - relacje Rosja-Zachód, Bliski Wschód jako ośrodek międzynarodowego terroryzmu, proliferacja broni nuklearnej oraz szeroko rozumiane bezpieczeństwo informacyjne.

Z oczywistych względów geopolitycznych stan stosunków między Federacją Rosyjską a wspólnotą transatlantycką stanowi przedmiot żywego zainteresowania polskiego środowiska studiów strategicznych. Nie jest zaskakujące, iż w dyskursie politycznym, medialnym i eksperckim dominuje krytyka aktualnej polityki rosyjskiej wobec Europy Wschodniej oraz przekonanie, iż zasadnicza odpowiedzialność za obecny antagonizm spoczywa po stronie reżimu prezydenta Władimira Putina. Warto podkreślić, iż za opiniami takimi stoją istotne przesłanki prawne, polityczne i etyczne. Tym nie mniej, do obowiązków środowiska naukowego należy także krytyczna analiza dominujących interpretacji oraz prezentacja alternatywnych wyjaśnień omawianych wydarzeń. Krytyczne zestawienie przeciwstawnych poglądów w rzeczowej dyskusji przyczynia się do lepszego zrozumienia obserwowanych procesów oraz postępu nauki. Z tego względu na uwagę zasługują publikacje prezentujące odmienną perspektywę analizy obecnej sytuacji w naszym regionie i wchodzące w polemikę $\mathrm{z}$ dominującymi poglądami. Należą do nich z pewnością artykuły Stanisława Bielenia (NATO - czas przewartościowań) (Bieleń, 2016) oraz Konstantina Khudoleya (Russia and the European Union: The Present Rift and Chances for Future Reconciliation) (Khudoley, 2016) opublikowane na łamach „Stosunków Międzynarodowych”.

Konstantin Khudoley, profesor Uniwersytetu Państwowego w Sankt Petersburgu, prezentuje rzeczową i wyważoną analizę obecnego stanu stosunków między Federacją Rosyjską a Unią Europejską. Na samym początku przedstawia argumenty przeciwko poglądowi, iż mamy do czynienia z nowa zimna wojna. Zwraca mianowicie uwage na trzy aspekty obecnej sytuacji w relacjach Rosja-Zachód. Po pierwsze, w przeciwieństwie do historycznej Zimnej Wojny, obecny antagonizm nie ma charakteru globalnego, wiele państw zachowuje neutralność w tym sporze (w zasadzie oryginalna Zimna Wojna również nie była tak wszechogarniająca). Po drugie, obecnie brakuje zasadniczego paliwa zimnej wojny, czyli zupełnej przeciwstawności systemów społeczno-politycznych. Khudoley ocenia, iż: „Chociaż systemy społeczno-polityczne i społeczno-gospodarcze współczesnej Rosji oraz krajów zachodnich znacząco się od siebie różnią ich sprzeczności nie mają charakteru antagonistycznego. Stanowią raczej konflikt dwóch odmian kapitalizmu - podtypów państwowego i prywatnego [...]" (Khudoley, 2016: 196). Po trzecie w końcu, konfrontacja zimnowojenna rządziła 
się pewnymi formalnymi i nieformalnymi regułami, ustalonymi chociażby w ładzie jałtańsko-poczdamskim czy Akcie Końcowym KBWE. Obecnie takiego „niepisanego porozumienia" mocarstw brakuje co rodzi sytuację, w której konflikty lokalne mogą łatwiej wymknąc się spod kontroli.

Autor omawianego artykułu źródeł antagonizmu na linii FR-UE upatruje w konkurencji i ostatecznie zderzeniu dwóch procesów integracyjnych - (zachodnio)europejskiego oraz eurazjatyckiego. To właśnie ta sprzeczność (określana też w interesujący sposób przez S. Charapa i M. Troitskiy'ego jako dylemat integracyjny; Charap, Troitskiy, 2013) okazała się być w przypadku Ukrainy nieprzezwyciężalna. W tym kontekście szczególnie interesujący jest podejmowany przez Khudoleya wątek zmiany postrzegania Unii Europejskiej przez rosyjskich przywódców na przestrzeni ostatnich kilkunastu lat. $Z$ organizacji, która może być partnerem we wspólnych projektach gospodarczych UE stała się konkurentem na obszarze poradzieckim i źródłem potencjalnego zagrożenia dla rosyjskiego reżimu. Khudoley ocenia, iż zdecydowana poprawa relacji FR-UE w perspektywie krótkoterminowej jest mało prawdopodobna. Wynika to z dwóch zasadniczych przesłanek. Po pierwsze, przywódcy Zachodni zainwestowali na tyle duży kapitał polityczny w przekonanie swoich wyborców, iż Rosja stanowi zagrożenie, iż elity i społeczeństwa państw UE stały się swego rodzaju zakładnikami antyrosyjskiej retoryki. W ciekawy sposób współgra to z analizą Roberta Legvolda, którego zdaniem mamy obecnie do czynienia z nowq zimnq wojnq w relacjach RosjaZachód. Kryteria, które przedstawia na poparcie tej tezy jednoznacznie odnoszą się do sfery wzajemnego postrzegania i braku zaufania między antagonistami (Legvold, 2016: 28-30). Jest to w zasadzie jeden ze sposobów rozpatrywania zimnej wojny, najbliższy dorobkowi szkoły konstruktywistycznej w nauce o stosunkach międzynarodowych. Po drugie, Khoduley zauważa, iż ,podejścia konceptualne Rosji i UE do przyszłego systemu stosunków międzynarodowych nie tylko różnią się od siebie, ale w rzeczy samej są przeciwstawne w szeregu istotnych aspektów" (Khoduley, 2016: 203). Za główny punkt sporny uznaje się tutaj rosyjskie oczekiwania ponownego podziału Europy na strefy wpływów, który dla Unii Europejskiej jest nie do zaakceptowania, gdyż kłóci się nie tylko z jej materialnymi interesami, ale całą wizją pożądanego kształtu ładu międzynarodowego wypływającą ze wspólnych jej członkom wartości.

Mimo tych istotnych różnic, rosyjski autor dostrzega możliwość pojednania i powrotu do współpracy między FR a UE w oparciu o wspólne interesy. Nie zaskakuje, iż rzeczonej wspólnoty interesów dopatruje się on w dążeniu do stabilizacji Bliskiego Wschodu i przeciwstawieniu się islamistycznemu terroryzmowi. Co interesujące, Khoduley zwraca również uwagę na dążenie Rosji do zachowania statusu odrębnego bieguna w obecnym ładzie międzynarodowym - samodzielnego nie tylko względem obecnego supermocarstwa (USA), ale także rosnącej w siłę ChRL. W opinii omawianego autora stanowi to kolejną płaszczyznę zbieżności między interesami Rosji i Unii Europejskiej. Uważa on bowiem, iż UE (czy może raczej tworzące ją państwa) również przejawiają ambicję zachowania statusu niezależnego gracza w polityce światowej. Można zatem pokusić się o stwierdzenie, iż Khudoley dostrzega potencjał współpracy Rosji i Unii Europejskiej celem wytworzenia/zachowania świata wielobiegunowego wobec rysującej się perspektywy układu dwubiegunowego z czołowymi rolami USA i ChRL. Pewnym mankamentem analizy zawartej w omawianym artykule może być 
traktowanie UE jako jednolitego aktora w stosunkach międzynarodowych. $Z$ jednej strony nie jest to zupełnie nieuzasadnione w kontekście relacji z Rosja, w końcu jednomyślność odnośnie sankcji została utrzymana. $\mathrm{Z}$ drugiej jednak w gronie 28 (jeszcze) państw członkowskich poglądy odnośnie właściwego kształtu relacji z USA, ChRL i FR są na tyle zróżnicowane, iż trudno mówić o w pełni spójnej polityce.

O ile zaprezentowany powyżej artykuł stanowi dość wyważoną analizę sytuacji w Europie Wschodniej, to artykuł Stanisława Bielenia stanowi otwartą polemikę z obecnym kształtem polityki RP i szerzej NATO wobec Rosji (o wyraźnie publicystycznym zacięciu). Autor ten krytycznie ocenia kierunki ewolucji Sojuszu Północnoatlantyckiego po zakończeniu zimnej wojny. Uznaje on, iż NATO stało się instrumentem unilateralnej polityki Stanów Zjednoczonych motywowanej demokratycznym mesjanizmem. Było to możliwe dzięki świadomej rezygnacji przez Europę Zachodnią $\mathrm{z}$ geopolitycznej podmiotowości w zamian za amerykańskie gwarancje bezpieczeństwa. W opinii Bielenia polityka ta przyniosła skutki odwrotne od zamierzonych i doprowadziła do destabilizacji Bliskiego Wschodu. Autor ten następnie przekonuje, iż obecne ochłodzenie relacji NATO-Rosja jest celowym zabiegiem amerykańskiej polityki zagranicznej mającym na celu odnowienie i wzmocnienie spójności Sojuszu Północnoatlantyckiego. Politykę taką uważa za błędną stwierdzając, iż: „potrzeba obecnie niezwykłej odwagi intelektualnej i przenikliwości analitycznej, aby oprzeć się wszechobecnej putinofobii i stwierdzić, że miejscem generowania najpoważniejszych zagrożeń nie są stabilne autokracje, lecz państwa w stanie dewastacji (państwa upadłe), na obszarze których rodzą się negatywne zjawiska grożące całemu cywilizowanemu [jakkolwiek autor go definiuje - przyp. RW] światu (patologie ustrojowe, armie terrorystów, masowy exodus ludności)" (Bieleń, 2016: 47).

Diagnoza ta jest niewątpliwie interesująca i w pełni logiczna z perspektywy realizmu politycznego. Rodzi jednak pewne pytania i wątpliwości, częściowo o charakterze naukowym, a częściowo dotykające ocen i poglądów politycznych. Stanisław Bieleń wyraźnie zaznacza, iż zachodnie interwencje militarne na Bliskim Wschodzie przyniosły przede wszystkim dalszą destabilizację tego obszaru. Jednocześnie jednak postuluje współpracę z Rosją na rzecz walki z (nie jest to nazwane wprost, jednak można to łatwo odczytać z kontekstu wypowiedzi) islamskim ekstremizmem oraz stabilizacji państw ,upadających”. W praktyce jednak musiałoby to oznaczać intensyfikację interwencji na obszarze Bliskiego Wschodu, czyli powtórzenie praktyk uznanych za nieskuteczne. Dodatkowo można by postawić pytanie - kto może stanowić większe zagrożenie dla obecnej pozycji międzynarodowej wspólnoty transatlantyckiej oraz korzystnego dla tego ugrupowania ładu międzynarodowego - transnarodowy ruch dżihadystyczny, zdolny do przeprowadzania spektakularnych i tragicznych, ale jednak ograniczonych w skutkach ataków czy podważające nienaruszalność granic w Europie mocarstwo nuklearne? Interesująca jest również jedna z uwag kończących omawiany artykuł: „Sojusz Północnoatlantycki musi powrócić do respektowania suwerenności historycznej i tożsamości geopolitycznej państw, które znajdują się w jego bezpośrednim sąsiedztwie. Nie może wywierać presji na te państwa, które jeszcze nie dojrzały do świadomego wyboru swoich afiliacji międzynarodowych" (ibid.: 50). Jasno jest tutaj wyrażona sugestia, iż Ukraina nie spełnia politycznych i ekonomicznych kryteriów członkostwa w Unii Europejskiej, a nawet podważana jest podmiotowość 
tego państwa w stosunkach międzynarodowych. Opinia ta nabiera ciekawego kontekstu w świetle doświadczeń historycznych Polski, która również długo była postrzegana przez niektóre środowiska w Europie Zachodniej jako państwo „niedojrzałe” do integracji transatlantyckiej.

Kolejnym stałym punktem agendy studiów strategicznych ostatnich lat jest niewątpliwie problem terroryzmu islamistycznego i rozwoju Państwa Islamskiego. Dobrym podsumowaniem dyskusji na ten temat są artykuły Michała Chorośnickiego (Kalifat - epizod czy trwaty element wspótczesnego terroryzmu) (Chorośnicki, 2016) oraz Sebastiana Wojciechowskiego (Terroryzm - stare i nowe dylematy) (Wojciechowski, 2016) opublikowane na łamach „Rocznika Strategicznego”. Obaj autorzy uważają Państwo Islamskie za jakościowo nową formę organizacji terrorystycznej stanowiącej wyzwanie o nowej skali dla swoich przeciwników. M. Chorośnicki zauważa, iż: „Państwo Islamskie używa terroryzmu jako narzędzia polityki, co nie jest niczym nowym, ale w takiej skali i konfiguracji pseudopaństwowej jeszcze nie występowało” (Chorośnicki, 2016: 387). Obaj autorzy zwracają uwagę na zespół czynników, które umożliwiły tej organizacji odniesienie spektakularnego sukcesu w postaci przejęcia na dłuższy czas kontroli nad względnie rozległym terytorium. Należą do nich chociażby umiejętne wykorzystanie mediów i propagandy, brutalność dokonywanych czynów, pozyskanie obfitych źródeł finansowania (S. Wojciechowski zaznacza, iż PI jest jak dotąd najbogatszą organizacją terrorystyczną w historii), zdolność przyciagnięcia licznych ochotników spoza regionu, hybrydowa forma walki czy strategia nowych frontów (afiliacja z grupami działającymi w różnych regionach świata, stanowiąca właściwie powtórzenie tzw. franczyzy Al-Kaidy) (Mendelsohn, 2011).

Co istotne, oba teksty wyraźnie ukazują znaczenie sprzyjających rozwojowi PI okoliczności politycznych, jakie zaistniały na Bliskim Wschodzie w ostatnich latach. Począwszy od amerykańskiej inwazji Iraku regionem wstrząsa pasmo konfliktów, które w coraz większym stopniu zazębiają się, tworząc rosnący kompleks niestabilności. PI jest skuteczne w rozszerzaniu swych wpływów na wszelkie obszary dotknięte osłabieniem struktur państwowych i konfliktami o często lokalnym charakterze. Niewątpliwie (co podkreślają obaj autorzy) PI jest w stanie przetrwać i rozwijać się tak długo z uwagi na podziały wśród jego przeciwników, które poważnie utrudniają skoordynowaną akcję przeciwko samozwańczemu kalifatowi. Jest to paradoksalna sytuacja, w której prawie wszyscy uczestnicy gry regionalnej na Bliskim Wschodzie należą do obozu wrogów PI. Jednak niejednokrotnie inne interesy są dla nich istotniejsze, co prowadzi do podziałów wewnątrz potencjalnej koalicji anty-PI. Istotna jest również uwaga $\mathrm{S}$. Wojciechowskiego, iż barierą dla skutecznej walki z terroryzmem jest niedostatecznie kompleksowe podejście do problemu. Zdaniem omawianego autora konieczne jest zwrócenie uwagi na problemy społeczno-ekonomiczne stanowiące paliwo dla terroryzmu. Oba omawiane artykuły stanowią dobre podsumowanie obecnego stanu debaty na temat korzeni sukcesu, charakteru oraz perspektyw na przyszłość Państwa Islamskiego.

Ciekawe uzupełnienie tematyki międzynarodowego terroryzmu stanowi artykuł Katarzyny Górak-Sosnowskiej pt. Zderadykalizować dżihadystę? Doświadczenia czterech państw muzutmańskich (Górak-Sosnowska, 2016) opublikowany na łamach „Rocznika Bezpieczeństwa Międzynarodowego”. Autorka podejmuje ciekawy, choć 
rzadziej eksplorowany $\mathrm{w}$ analizach aspekt przeciwdziałania terroryzmowi. Należy przecież pamiętać, iż terroryzm sam w sobie jest strategią walki, motywację dla której stanowi określona radykalna ideologia. Biorąc pod uwagę, iż terroryści oddziałują na swoje cele przede wszystkim na płaszczyźnie psychologicznej, skuteczna walka z nimi również musi odbywać się na tym polu. K. Górak-Sosnowska poddaje analizie programy deradykalizacyjne uruchomione na przestrzeni ostatnich dwóch dekad w czterech państwach muzułmańskich: Arabii Saudyjskiej, Egipcie, Indonezji i Jemenie. Każdy z nich stanowił odmienne podejście do problemu. Różnią się one chociażby w takich aspektach jak: równowaga między teologicznymi a świeckimi komponentami programu, kategorie objętych nimi osób czy zakres materialnego wsparcia udzielanego $a b$ solwentom.

Co nie zaskakuje, jednoznaczna ocena skuteczności analizowanych programów nie jest sprawą łatwą. Jak podkreśla autorka omawianego artykułu, łatwiejszym jest osiagnięcie deradykalizacji na poziomie behawioralnym (zmiana zachowania) niż kognitywnym (zmiana poglądów). Zagadnienie to dotyka jednego z najpoważniejszych i najtrudniejszych pytań związanych z tego typu działaniami: czy w sytuacji gdy ludzkie myśli pozostają nieprzeniknione dla aparatury badawczej będziemy w stanie kiedykolwiek stwierdzić czy deradykalizacja kognitywna faktycznie nastapiła? Z drugiej strony można argumentować, iż z punktu widzenia władz wystarczającym efektem jest deradykalizacja behawioralna oznaczająca zaprzestanie działalności ekstremistycznej. Górak-Sosnowska zauważa, iż program saudyjski ma najbardziej kompleksowy charakter. Uwzględnia on bowiem zarówno dyskusje teologiczne, jak i terapię psychologiczną oraz wsparcie materialne dla kończących go osób. Niebagatelne znaczenie miało również zaangażowanie w cały proces rodzin ekstremistów. Jak jednak zauważa autorka, podejście takie było możliwe w dużej mierze dzięki specyficznym uwarunkowaniom politycznym, społecznym i gospodarczym Arabii Saudyjskiej. Dodatkowo, procesowi poddawano wyłącznie osoby podejrzewane o sympatyzowanie z lub wspieranie działalności terrorystycznej, ale już nie ekstremistów, którzy dokonali aktów przemocy. Omawiany artykuł w ciekawy i kompleksowy sposób pokazuje znaczenie zabiegów deradykalizacyjnych dla wszechstronnego i skutecznego przeciwdziałania terroryzmowi. Jednocześnie jednak jego lektura uświadamia, iż jest to proces niezwykle złożony, delikatny o niepewnych szansach powodzenia. Wydaje się jednak, iż doświadczenia omówionych państw muzułmańskich mogą być co najmniej interesujące dla państw zachodnich mierzących się z rosnącą radykalizacją części społeczności muzułmańskich.

Ciekawe uzupełnienie dyskusji nt. zagrożenia ze strony Państwa Islamskiego stanowi artykuł Arkadiusza Domagały pt. Przesłanki i bariery interwencji humanitarnej na przykładzie Libii (2011) i Syrii (2013), (Domagała, 2016) opublikowany na łamach „Stosunków Międzynarodowych”. Jak podkreślali w omawianych wcześniej tekstach M. Chorośnicki i S. Wojciechowski, jednym z zasadniczych czynników powstania, rozwoju i sukcesu tej organizacji była/jest destabilizacja powodowana przez toczące się na Bliskim Wschodzie konflikty zbrojne. Wojna domowa w Syrii pozwoliła Islamskiemu Państwu Iraku na przekształcenie się w obecny samozwańczy kalifat. Jednocześnie nowe fronty działalności Państwa Islamskiego powstają na obszarach dotkniętych konfliktami, jak np. w Libii, Jemenie czy Nigerii. Wobec takiej sytuacji 
często pojawiają się pytania odnośnie wpływu aktorów zewnętrznych na lokalne konflikty oraz możliwość stabilizacji sytuacji na drodze interwencji państw trzecich. Wiąże się to z szerszą dyskusją nt. tzw. Odpowiedzialności za ochronę (ang. Responsibility to Protect - R2P). Słuszność i celowość przyjęcia tej koncepcji jako obowiązującej reguły funkcjonowania systemu międzynarodowego jest przedmiotem zażartej debaty. Celem omawianego artykułu nie jest zabranie w niej głosu, ale raczej ,,wskazanie na warunki i okoliczności, które mogą stać się czynnikami utrudniającymi lub ułatwiającymi realizację celów interwencji humanitarnej [...]" (Domagała, 2016: 158).

Autor omawianego artykułu identyfikuje i analizuje szereg czynników decydujących o powodzeniu takiego przedsięwzięcia. Należą do nich: siła potencjalnego interwenta; przyjęta strategia neutralizacji potencjalnego przeciwnika; możliwość precyzyjnego określenia celów w wymiarze politycznym i humanitarnym; warunki klimatyczne, przyrodniczo-geograficzne oraz infrastrukturalne; możliwości efektywnego wykorzystania zasobów logistycznych interwenta; przewidywana determinacja interwenta $\mathrm{w}$ realizacji celu; klarowna sytuacja polityczna w państwie będącym przedmiotem interwencji; zakres powiązań prawnomiędzynarodowych i politycznych państwa - przedmiotu interwencji oraz legitymizacja działań interwenta. Tak stworzona lista uwarunkowań pozwala następnie na analizę dwóch przypadków - interwencji międzynarodowej w Libii (2011 r.) oraz sytuacji Syrii w roku 2013, kiedy to Zachód ostatecznie powstrzymał się od interwencji w odpowiedzi na użycie przez reżim Baszara Al-Assada broni chemicznej. Domagała dochodzi do wniosku, iż w przypadku Libii wystapił zbieg czynników wyjątkowo sprzyjający skutecznej interwencji (naturalnie mowa tutaj o krótkoterminowym powodzeniu - obaleniu reżimu, nie odnosząc się do długofalowej stabilizacji państwa). Tymczasem w odniesieniu do Syrii było niemal zupełnie odwrotnie, układ determinant interwencji był zdecydowanie niekorzystny dla jej zwolenników. Należy tutaj zwrócić uwagę na takie czynniki jak: znaczna zdolność reżimu Assada do stawienia skutecznego oporu, silne wsparcie ze strony mocarstw (przede wszystkim Federacji Rosyjskiej) oraz brak jedności politycznej po stronie przeciwników reżimu. Warto szczególną uwagę zwrócić na ten ostatni czynnik. Jak zauważa A. Domagała: „Z punktu widzenia interwenta sytuacją pożądaną byłoby, aby ludność cywilna, której prawa są naruszane w danym państwie, popierała jedno, względnie spójne ugrupowanie polityczne, mające własne struktury (para)militarne" (ibid.: 163). Oczywistością jest, iż w przypadku Syrii ten warunek nie był spełniony. Dodatkowo można zauważyć, iż reżim Assada podejmował celowe działania zmierzające do wzmocnienia ekstremistycznych segmentów rebelii, zapewne po to, aby uczynić zewnętrzną interwencję mniej atrakcyjną opcją.

Niewątpliwą siłą omawianego artykułu jest rzeczowa analiza pragmatycznych uwarunkowań decyzji mocarstw o podjęciu interwencji humanitarnej. Zawsze bowiem rozważając perspektywy podjęcia tego typu działań należy zadać nie tylko pytanie: Czy jest to słuszne i polepszy los ludności cywilnej? ale także (a może przede wszystkim), czy będzie to opłacalne dla potencjalnych interwentów? Choć artykuł A. Domagały nie odnosi się wprost do kwestii Państwa Islamskiego, to jednak zachodnie interwencje na Bliskim Wschodzie stanowią istotny kontekst dla historii tej organizacji. Z jednej strony powszechnym stało się przekonanie, iż destabilizacja Iraku w wyniku amerykańskiej inwazji i okupacji stała się ważnym czynnikiem umożliwiającym powstanie 
i rozwój tej organizacji. Destabilizacja Libii, która nastąiła po obaleniu reżimu Kadafiego również jest przytaczana jako przykład szkodliwych skutków, wojujacego humanitaryzmu. Z drugiej strony pojawiają się głosy takie, jak opinia M. Chorośnickiego: „Obecna taktyka Zachodu wobec poważnego globalnego problemu sprowadza się do odsuwania radykalnych rozwiązań w czasie (nie wchodzi w grę interwencja lądowa) i próby załatwienia własnych spraw cudzymi rękami” (Chorośnicki, 2016: 392). Artykuł A. Domagały nie oferuje odpowiedzi na tak zarysowany dylemat, nie taki zresztą jest jego cel. Jednak zestawienie przypadków Libii i Syrii pozwala na interesującą refleksję. Jeżeli przyjmiemy, iż obecny stan Libii jako państwa de facto upadłego jest rezultatem nietrafionej interwencji humanitarnej, to możemy uznać, iż to doświadczenie wpłynęło na decyzję zachodnich przywódców o zaniechaniu podobnych kroków względem Syrii. W praktyce jednak sytuacja Syrii jest obecnie zbliżona do libijskiej i to bez interwencji humanitarnej. Można by to uznać za dowód na to, iż lokalnymi konfliktami rządzi lokalna dynamika, na którą zewnętrzni interwenci mogą wpłynąć tylko w niewielkim stopniu. Można jednak również argumentować, iż eskalacja konfliktu syryjskiego, ze wszystkimi negatywnymi dla Zachodu efektami (PI, migracje) jest efektem braku interwencji i faktycznej bezczynności. Jeżeli lekcją Iraku i Libii miałaby być dyrektywa: „lepiej nie interweniować w takich konfliktach, gdyż może to jedynie pogorszyć sytuacje”, to być może lekcją Syrii jest: „taki konflikt w końcu i tak zrodzi niestabilność, która dotknie nas wszystkich, lepiej reagować wcześniej i ograniczać szkody niż bezczynnie czekać aż problem urośnie do rozmiarów nie pozwalających dłużej go ignorować". Pytanie pozostaje otwarte.

Kolejnym istotnym punktem agendy współczesnych rozważań nad bezpieczeństwem międzynarodowym jest problem proliferacji broni nuklearnej. W obliczu obecnych wyzwań reżimu nieproliferacji, związanych z przypadkami Korei Północnej oraz Iranu, interesującym pozostaje pytanie o możliwość integracji z nim nowych państw nuklearnych. W artykule pt. Trustworthy Nuclear Sovereigns? India and Pakistan after the 1998 tests (Sullivan de Estrada, Wheeler, 2016) opublikowanym na łamach „Stosunków Międzynarodowych” Kate Sullivan de Estrada i Nicholas J. Wheeler proponują interesującą interpretację wydarzeń prowadzących do de facto legalizacji indyjskiego arsenału nuklearnego. Punktem wyjścia dla tych rozważań jest rozbieżność międzynarodowego statusu dwóch młodych potęg nuklearnych regionu Azji Południowej. Po testach nuklearnych 1998 r., zarówno Indie, jak i Pakistan stały się obiektem międzynarodowych sankcji. Jednak obecnie, prawie dwie dekady później, Indie uzyskały faktyczną akceptację wspólnoty międzynarodowej dla swojego nuklearnego statusu czego przejawem jest porozumienie o współpracy w dziedzinie cywilnego wykorzystania energii nuklearnej zawarte z USA oraz akceptacja Indii przez Grupę Dostawców Nuklearnych (ang. Nuclear Suppliers Group - NSG). W tym samym czasie, Pakistan nie uzyskał tego typu przywilejów i do pewnego stopnia nadal jest traktowany jak ,nuklearny parias”.

Sullivan de Estrada i Wheeler przytaczają na wstępie najpopularniejsze wyjaśnienia szczególnego traktowania Indii: materialne (interes USA i innych państw w rozwoju współpracy politycznej i gospodarczej z Indiami) oraz normatywne (pokrewieństwo ustrojowe wobec demokratycznych Indii). Chociaż oboje autorów uznaje te koncepcje za istotne dla wyjaśnienia pozycji Indii, to jednak uważają za istotne uzupełnienie ich 
kolejnym elementem - konsekwentną budową przez Indie własnego wizerunku jako państwa godnego zaufania w odniesieniu do broni jądrowej. Autorzy omawianego artykułu zwracają uwagę na fakt, iż już krótko po testach w 1998 r. władze indyjskie zaczęły podkreślać swą akceptację dla szeregu norm międzynarodowych związanych $\mathrm{z}$ bronią nuklearną (jak chociażby moratorium na dalsze testy nuklearne). Przekaz ten jedynie umocnił się w wyniku konfliktu kargilskiego, kiedy to zewnętrzni obserwatorzy zwrócili uwagę na cywilną kontrolę nad siłami zbrojnymi oraz indyjskie samoograniczenie w zakresie naruszenia Linii Kontroli w Kaszmirze. Wszystkie te elementy mocno kontrastowały ze stanowiskiem i postawą Pakistanu. Zdaniem autorów omawianego artykułu skuteczna budowa własnego wizerunku jako godnej zaufania potęgi nuklearnej odegrała kluczową rolę w przekonaniu USA (najważniejszego odbiorcy) oraz szerzej wspólnoty międzynarodowej do faktycznej „legalizacji” indyjskiego potencjału nuklearnego.

Nie ulega wątpliwości, iż decyzje podejmowane w ramach reżimów międzynarodowych (jak np. reżimu nieproliferacji) są wypadkową zarówno czysto materialnych interesów, jak i przesłanek normatywnych. Jednak uwaga o znaczeniu zaufania, wizerunku i narracji jest cenna i ma znaczenie zwłaszcza w negocjacjach. W ten sposób można znaleźć powiązania między artykułem Sullivan de Estrady i Wheelera a tekstem Radosława Fiedlera pt. Negocjacje amerykańsko-irańskie w kwestii nuklearnej. Analiza na podstawie modelu negocjacji nastawionych na wspótpracę ,, wygrana-wygrana" (również w „Stosunkach Międzynarodowych”) (Fiedler, 2016). Artykuł ten stanowi analizę rozmów prowadzących do zawarcia w lipcu 2015 r. porozumienia między Iranem a Grupą P5+1 w zakresie programu nuklearnego tego pierwszego z punktu widzenia zidentyfikowanego przez specjalistów z Harvard Law School modelu negocjacji integracyjnych wygrana-wygrana. Opiera się on na czterech głównych założeniach: oddzieleniu ludzi od problemów; koncentracji na interesach zamiast na stanowiskach; poszukiwaniu różnych wariantów rozwiązania problemu oraz stosowaniu obiektywnych kryteriów. W opinii prof. Fiedlera w toku kilkuletnich negocjacji obu stronom udało się przejść od negocjacji pozycyjnych do negocjacji według modelu wygranawygrana, co doprowadziło do zawarcia porozumienia, które według jego twórców ma zahamować irański program nuklearny na ok. dekadę. Wymagało to niewątpliwie budowy sporego kapitału zaufania, przede wszystkim między USA a Iranem. Przywódcy obu tych państw od czasów rewolucji islamskiej postrzegają się nawzajem jako wrogów.

Jak zaznacza autor omawianego artykułu, wynegocjowane porozumienie nie doprowadziło do całkowitego przewartościowania relacji na Bliskim Wschodzie. Jednym z największych ograniczeń dla realizacji umowy jest sprzeciw istotnych aktorów regionalnych (Arabia Saudyjska, Izrael), jak również nieuwzględnienie w niej szerszego problemu konfliktów regionalnych, w które zaangażowany jest Iran. Bez względu na ocenę szczegółów porozumienia, nie ulega wątpliwości, iż jego pomyślna realizacja zależy w znacznym stopniu od budowy przez Iran wizerunku partnera godnego zaufania. Co interesujące i paradoksalne zarazem, początek urzędowania nowej administracji prezydenta Donalda Trumpa przyniósł niepewność co do chęci wypełniania przez USA postanowień porozumienia nuklearnego z Iranem. Choć sprawa ta jest skomplikowana oraz niejednoznaczna i nie powinna być rozpatrywana w ode- 
rwaniu od szerszego kontekstu sytuacji w regionie, to jednak nie sposób nie docenić ironii sytuacji, w której to USA stają się potencjalnie aktorem, który musi potwierdzać/ budować zaufanie odnośnie swoich zobowiązań.

Ważnym aspektem współczesnego międzynarodowego środowiska bezpieczeństwa jest rosnące znaczenie i zainteresowanie problemem tzw. bezpieczeństwa informacyjnego. Sfera ta dotyczy przede wszystkim możliwości manipulacji informacją docierającą do opinii publicznej celem wywołania pożądanego efektu strategicznego. Mamy wręcz do czynienia ze swoistą sekurytyzacją przekazu medialnego, w ramach której coraz więcej państw i organizacji podejmuje działania celem ochrony przed fałszywymi wiadomościami i propagandą. Wydaje się, iż w tym obszarze wciąż dociera do nas więcej publicystyki niż rzetelnych badań. Nie zmienia to jednak faktu, iż temat jest istotny i podejmowany przez autorów publikujących na łamach polskiej prasy naukowej. W tym kontekście warto odwołać się do dwóch artykułów podejmujących tą tematykę niejako z przeciwstawnych biegunów: Bohdan Pac Integracja wojny informacyjnej $i$ hybrydowej w konfliktach międzynarodowych („Bellona”) (Pac, 2016) oraz Jarosław Tomasiewicz Mgławica rebelii. Terroryzm w społeczeństwie informacyjnym na przykładzie insurekcjonizmu („Rocznik Bezpieczeństwa Międzynarodowego”) (Tomasiewicz, 2016). Pierwszy tekst prezentuje interesujący model integracji technik wojny informacyjnej z modelem wojny hybrydowej. Porównując działania Niemiec wobec Czechosłowacji w 1938 r. oraz Rosji w stosunku do Ukrainy (2014-2015) prezentuje kompleksowy obraz strategii działań informacyjnych obliczonych na zdominowanie „środków ciężkości na szczeblu strategicznym i operacyjnym” w postaci morale i systemu wartości; percepcji i procesu podejmowania decyzji oraz zasobów decydujących o sile państwa i narodu. Stanowi to ciekawą analizę sposobu wykorzystania narzędzi informacyjnych dla wsparcia szerszej, hybrydowej strategii oddziaływania na przeciwnika.

Z kolei artykuł Jarosława Tomasiewicza próbuje ukazać jak współczesne technologie informacyjne ułatwiają funkcjonowanie nowego typu rozproszonej struktury terrorystycznej. Autor omawianego artykułu analizuje tutaj ideę insurekcjonizmu, która narodziła się w środowisku włoskiej skrajnej lewicy. Miał to być nowy rodzaj działalności terrorystycznej, odmienny od scentralizowanych organizacji doby zimnej wojny. Miał on działać na zasadach oporu niekierowanego, którego istotą jest: ,,[...] autonomiczna działalność komórek o wyspecjalizowanych funkcjach, operujących na trzech poziomach: legalnym, półlegalnym i nielegalnym. Komórki nie są powiązane więzami organizacyjnymi, spoiwem całego ruchu jest wspólny światopogląd uformowany i podtrzymywany poprzez sieć komunikacji” (Tomasiewicz, 2016: 56-57). Jak zauważa Tomasiewicz idee te zostały wprowadzone w życie między innymi przez anarchistów greckich z grup Konspiracyjne Komórki Ognia (Synomosia Pyrinon tis Fotias) i Walka Rewolucyjna (Epanastatikos Agonas) (ibid.: 56). Jest to zatem zupełnie inny wymiar walki informacyjnej (i nie tylko), niż ten, który opisuje B. Pac. Zamiast centralnie sterowanej i idealnie zsynchronizowanej kampanii państwowej mowa tu raczej o, do pewnego stopnia, chaotycznych działaniach niemal całkowicie zdecentralizowanej organizacji. Oba teksty stanowią ciekawe ujęcie coraz bardziej doniosłego problemu. Pozostaje naturalnie pytanie o najlepsze sposoby przeciwstawiania się tak rozumianym zagrożeniom informacyjnym. B. Pac pisze, że „koniecznością jest posia- 
danie własnej narodowej strategii obrony przeciw wojnie informacyjnej w ramach tak zwanej strategicznej komunikacji na szczeblu narodowym. Komunikacja ta obejmuje zastosowanie skoordynowanych i odpowiednio dopasowanych działań oraz zdolności komunikacyjnych państwa, czyli dyplomacji, publicznej działalności prasowo-informacyjnej, wojskowej działalności prasowo-informacyjnej, operacji informacyjnych oraz działań (operacji) psychologicznych, na potrzeby wsparcia polityki państwowej, a także podjęcia działań i operacji w imię osiagania własnych celów narodowych" (Pac, 2016: 77). Można jednak postawić pytanie, czy nie jest to podejście nazbyt zmilitaryzowane i odgórne. Ciekawą perspektywą w kontekście państw demokratycznych wydaje się być połączenie wielu elementów przeciwdziałania, w tym krytycznej edukacji medialnej obywateli (Wiśniewski, Kania, Filipiak, 2015).

Podsumowując powyższy przegląd polskich analiz strategicznych 2016 roku należy stwierdzić, iż dynamiczne procesy kształtujące międzynarodowe środowisko bezpieczeństwa dostarczyły bogatego materiału do badań prowadzonych w ramach studiów strategicznych. Za szczególnie pozytywny trend należy uznać zdecydowanie częstsze niż w poprzednich latach podejmowanie tematyki dotyczącej bezpieczeństwa obszarów pozaeuropejskich (choć naturalnie z implikacjami dla Europy). Ważnym poszerzeniem pola badawczego są również studia nad bezpieczeństwem informacyjnym. Wszystko to pozwala na nakreślenie szerszego (tak w rozumieniu geograficznym, jak i funkcjonalnym) przyszłego programu badawczego polskich studiów strategicznych.

\section{Bibliografia}

Bieleń S. (2016), NATO - czas przewartościowań, „Stosunki Międzynarodowe”, t. 52, nr 1.

Charap S., Troitskiy M. (2013), Russia, the West and the Integration Dilemma, „Survival: Global Politics and Strategy", Vol. 55, No. 6.

Chorośnicki M. (2016), Kalifat - epizod czy trwały element współczesnego terroryzmu?, „Rocznik Strategiczny" 2015, nr 16.

Domagała A. (2016), Przesłanki i bariery interwencji humanitarnej na przykładzie Libii (2011) i Syrii (2013), „Stosunki Międzynarodowe”, t. 52, nr 3.

Fiedler R. (2016), Negocjacje amerykańsko-irańskie w kwestii nuklearnej. Analiza na podstawie modelu negocjacji nastawionych na wspótprace „wygrana-wygrana”, „Stosunki Międzynarodowe", t. 52, nr 3.

Górak-Sosnowska K. (2016), Zderadykalizować dżihadystę? Doświadczenia czterech państw muzulmańskich, „Rocznik Bezpieczeństwa Międzynarodowego”, Vol. 10, nr 2.

Khudoley K. (2016), Russia and the European Union: the Present Rift and Chances for Future Reconciliation, „Stosunki Międzynarodowe”, t. 52, $\mathrm{nr} 2$.

Legvold R. (2016), Return to Cold War, Cambridge.

Mendelsohn B. (2011), Al-Qaeda's Franchising Strategy, „Survival: Global Politics and Strategy”, Vol. 53, No. 3.

Pac B. (2016), Integracja wojny informacyjnej i hybrydowej w konfliktach międzynarodowych, „Bellona”, nr 1.

Sullivan de Estrada K., Wheeler N. J. (2016), Trustworthy Nuclear Sovereigns? India and Pakistan after the 1998 tests, „Stosunki Międzynarodowe”, t. 52, nr 2. 
Tomasiewicz J. (2016), Mgławica rebelii. Terroryzm w społeczeństwie informacyjnym na przykładzie insurekcjonizmu, „Rocznik Bezpieczeństwa Międzynarodowego”, Vol. 10, nr 2.

Wiśniewski R., Kania E., FilipiakA. (2015), News Literacy jako narzędzie edukacji dla bezpieczeństwa $w$ erze rewolucji cyfrowej, w: Media $w$ systemie bezpieczeństwa narodowego, (red.) M. Skarżyński, I. Andruszkiewicz, Poznań.

Wojciechowski S. (2016), Terroryzm - stare i nowe dylematy, „Rocznik Strategiczny” 2015, nr 16.

\title{
STRESZCZENIE
}

Niniejszy artykuł stanowi kolejną odsłonę przygotowywanego od dwóch lat przeglądu artykułów publikowanych w wybranych polskich czasopismach naukowych poświęconych tematyce bezpieczeństwa międzynarodowego. W odniesieniu do roku 2016 autor dokonał (siłą rzeczy) subiektywnego wyboru tekstów, które znalazły się na łamach czterech publikacji - „Bellony”, „Rocznika Bezpieczeństwa Międzynarodowego”, „Rocznika Strategicznego” oraz „Stosunków Międzynarodowych". W naturalny sposób tematyka podejmowana przez autorów rzeczonych publikacji stanowi odzwierciedlenie obecnego stanu międzynarodowego środowiska bezpieczeństwa oraz prognoz co do kierunków jego dalszej ewolucji.

Slowa kluczowe: studia strategiczne, terroryzm, interwencja humanitarna, bezpieczeństwo informacyjne

\section{POLISH STRATEGIC ANALYSES - 2016 IN REVIEW}

\begin{abstract}
This article is the third edition of a review of articles published in selected Polish academic journals in the field of international security. Covering the year 2016 the author has made a (necessarily subjective) selection of papers published in four periodicals: „Bellona”, „Rocznik Bezpieczeństwa Międzynarodowego” (International Security Yearbook), „Rocznik Strategiczny” (Strategic Yearbook) and „Stosunki Międzynarodowe” (International Relations). Inevitably the subjects taken up by authors of texts under review reflect the current state of the international security environment and prognosis on its future evolution.
\end{abstract}

Keywords: strategic studies, terrorism, humanitarian intervention, information security 